\title{
The Metropolitan Scale
}

\begin{abstract}
The growth of metropolitan areas is reshaping the urban landscape and governance around the world, producing new challenges but also opportunities for sustainable development and the management of territories. The 'metropolitan scale' is now internationally recognised as a key concept and perspective through which we should consider various socio-economic, spatial and political dimensions. However, our understanding of metropolitan dynamics is curtailed by a substantial lack of information at this scale. Global databases on metropolitan areas are very limited. To tackle the void, this paper employs simple definitions and heuristics to collect and present comparable data for 58 metropolises from five continents. There is a clear trade-off between the accuracy of the data and the comprehensiveness of datasets. We reflect on the experience to emphasise the obstacles that lie ahead of both scholars and policy-makers at all levels of government. A strong system of cities and metropolitan areas and the appropriate governance of these scales may provide the basis for a balanced socio-economic development - but first we will need to know more about these territories and communities.
\end{abstract}

Keywords: data; functional area; governance; metropolis.

\section{Introduction: the metropolis}

Cities, urban areas, urban agglomerations, megacities, metropolises, metropolitan areas, metropolitan statistical areas, functional areas, city-regions, urban regions, commuter belts, conurbations (...)

We often use these terms interchangeably to allude to the same realities on the ground. We do this because most of these concepts are fairly ambiguous in a global context. 'City', for example, may refer to a human settlement with specific characteristics, for instance linked to: certain population or employment densities, cultures and subcultures, the built environment and the prevalence of infrastructure systems, among others. Or it may refer to a territory within a boundary which, for similar or completely different reasons, has historically been considered a 'city' (e.g. the presence of a certain temple or government institution). These are not necessarily mutually exclusive categories. However, the former understanding of 'city' tends to be more useful as a context for analysis.

The notion of metropolitan area (or metropolis, and so on) suffers from similar issues. However, though it may simply be used to denote a large city, it is more often deliberately employed to designate an organically and dynamically-defined territory that extends beyond the core city (d'Albergo and Lefèvre, 2018). These large human settlements may or may not have any correspondence to administrative boundaries. Beyond political or institutional frameworks, what unifies the different jurisdictions and locales that constitute a metropolitan area are the economic and social relationships that occur within it, as well as the features of the built environment and infrastructures that enable these relationships (d'Albergo et al., 2018).

This mismatch between socio-political institutions and socio-technical systems and metropolitan areas challenges the effective management of territories (Guzman et al., 2017; Tomlinson, 2017). And, more broadly, these conceptual struggles present challenges for research and practice. First and 
foremost, there is a substantial lack of information at the metropolitan scale (especially when it comes to metrics that are essential for the governance of these territories or to the Global South in general). The scarcity of international databases stifles comparative research on metropolitan activities and governance. As an attempt to tackle this basic problem, this article presents a set of metropolitan indicators - including new and existing metrics - and the corresponding data for 58 of the members of Metropolis. ${ }^{1}$ We discuss the methodological steps taken in order to (1) select the indicators and data sources, (2) set the boundaries for the targeted metropolitan areas, and (3) build this comprehensive dataset. Our approach allows analysts and decision-makers to use existing data rather than calling on local authorities to collect and publish data at a different scale. While we briefly showcase some of the data collected, the emphasis is placed on the wider implications of the current state of empirical evidence on metropolitan areas.

The significance of urbanisation and urban areas for the $21^{\text {st }}$ century society is now widely acknowledged and does not need to be condoned here (Burdett and Rode, 2018). But why is it important to focus on and collect data at the metropolitan scale? One of the key reasons was already alluded to above. The frequent absence of metropolitan-wide governments - or of effective and democratic coordination mechanisms between the municipalities within a metropolitan areachallenges territorial management, policy-making and the delivery of public services, infrastructure and amenities. Even in the cases where these organisations or governments do exist, they tend to have few powers and responsibilities (Ahrend et al., 2014). The realities of how a metropolis works are connected to issues of taxation and voice and representation. Residents from other municipalities may heavily use local infrastructure services in the core city without paying their taxes there. 'Metropolitan citizens' residing outside the core city may not have the same rights of the ones living within its administrative limits - for example, when city-owned utilities operate in an extended territory and citizens residing outside the boundaries of the city cannot punish/reward incumbents with their vote (da Cruz et al., 2013). Generating data at the metropolitan scale is not sufficient to resolve these issues - that requires appropriate territorial governance and strategic management - but it certainly is necessary. We ought to understand the realities of where and how people live, work and play for urban policy to be coordinated and effective and so that institutions may work properly.

There are, however, other reasons. While administrative or political boundaries tend to be rigid, metropolitan areas are dynamic in their spatial, social, economic and environmental dimensions. Urban expansion hampers the bridging of geographical scales - in various senses, from the statistical to the institutional - because they keep shifting (Angel et al., 2012; Angel, 2017; da Cruz et al., 2019). Promoting functional integration is particularly difficult in rapidly urbanising areas of the Global South where the swift population growth tends to occur at the peripheries and urban hinterlands. This is significant because the relationships between cities and their surrounding areas can have a major influence on the location of economic activities, (national) growth, environmental performance and quality of life. Metropolitan areas compete for many resources in our globalised economy. And even when economic competitiveness is not a political priority, cities/metropolises may wish to identify their 'peers' around the globe to potentiate knowledge transfer. This requires a certain degree of standardisation. Finally. more than simply an issue of scale, it is an issue of fairness. Inequalities within metropolitan areas - e.g. in terms of access to income, services and amenities - can be more extreme than at other geographical scales (Phelps, 2010).

In the second section, we briefly review the state-of-the-art, tackle the challenges of selecting metropolitan level metrics and describe our approach to select a set of 37 indicators. In the third section, we revisit the most common procedures to define the boundaries of metropolitan areas and present our own pragmatic approach. Section four outlines the data collection process and section five the presents a summary of the results. The sixth section concludes the paper.

\footnotetext{
${ }^{1}$ Metropolis is the largest global network of major cities and metropolitan areas (most with at least one million inhabitants). This organisation serves as a hub and platform for 138 urban agglomerations to connect, share experiences, and mobilise on a wide range of local and global issues, in addition to being the focal point of worldwide experience and expertise on metropolitan governance.
} 


\section{Information at the metropolitan scale}

\subsection{Brief review of the state of the art}

In 2015, the United Nations prominently included 'cities' into the Sustainable Development Goals (SDGs) framework with the aim of making them more "inclusive, safe, resilient and sustainable". But, despite this recognition by global development actors and efforts, several challenges persist in terms of measuring the status quo of cities and tracking their development (Klopp and Petretta, 2017). Not having a robust framework for defining cities (as we have seen in the previous section, what do they even mean?) and measuring their key attributes, including processes to select indicators and collect data, suggests that it is impractical to assess how the current multilateral efforts to tackle urban problems have progressed. Still, various attempts have been made at the global level, particularly in the last decade.

The first version of Global Urban Indicators Data published in 1996 by UN-Habitat was an important milestone as the first attempt to provide an overview of cities all over the world, but successors to this initiative were infrequent for some time. By reviewing 17 studies that measured the sustainability of cities, Tanguay et al. (2010) concluded that they tended to only cover European and North American cases - except for a handful of initiatives such as the Urban Indicators for Managing Cities published by the Asian Development Bank in 2001 and focusing on Asian cities (Westfall and de Villa, 2001). In general, cities from the Global South have been excluded from many international databases (particularly in Africa and Southeast Asia). However, more inclusive initiatives have gradually been deployed, such as: UN-Habitat's City Prosperity Index, Siemens' Green City Index, and ISO 37120 on sustainable development of communities, which were announced in 2012, 2012 and 2014, respectively. There has also been more intensive activity around specific policy sectors or concerns, for example: UITP's Mobility in Cities Database of metropolitan areas, C40's interactive dashboard on city greenhouse gas emissions, UN-Habitat's Global Municipal Finance Database, Igarapé Institute's Fragile Cities initiative and, most recently, the Inter-American Development Bank's Urban Dashboard.

Two major theoretical challenges have been commonly discussed in the literature: what to measure and how to do it (Hoornweg et al., 2007). It should by now be common knowledge that crafting or choosing indicators is not merely a technical but also a political process (Klopp and Petretta, 2017). Which voices get to be heard and perspectives get to be valued? Who decides what gets measured, what does not get measured, and how it should be done? This is not to say that there are no areas for which measurement at the metropolitan level truly makes more technical sense. The rationale for demographic (e.g. population density and diversity), land use (e.g. green, industrial and commercial areas) and economic (e.g. employment and wealth distribution) data is fairly self-evident. As is the value of having metropolitan-level data on sectors with clear economies of scale - above all, urban infrastructure services such as transport, wastewater treatment, and municipal waste management. ${ }^{2}$ Naturally, better definitions and more data at the metropolitan scale would not by themselves contribute necessarily to a more balanced development. This would require appropriate governance mechanisms. On this point, there is recent literature referring to the benefits of having strategic governance at the metropolitan scale, particularly in the transport and spatial planning sectors (OECD, 2015; Rode et al., 2019).

There are also practical obstacles to the 'whats' and 'hows' of measurement, mostly connected to data availability and data collection capability (Klopp and Petretta, 2017). While notable progress has been made to meet theoretical challenges - e.g. standardisation of indicators such as ISO 37120 - practical challenges have been difficult to surmount. For example, when looking into the World Council on

\footnotetext{
${ }^{2}$ In addition to the economies of scale (and scope and density), transport infrastructure sets up patterns of urban growth (Baum-Snow, 2007) and enact considerable path dependencies and lock-in effects that impact future development (Stern and Zenghelis, 2018).
} 
City Data (WCCD)'s Global Cities Registry ${ }^{\mathrm{TM}}$, except for Buenos Aires and some cities in Mexico, no African or other Latin America and Caribbean cities have been able to collect all data for its 46 core indicators since its inception in 2014 (Gómez-Álvarez et al., 2017). The analysis of the latest version of the United Nation's World Cities Report published in 2016 is still partially based on data measured in the 1990s. Moving from the city to the metropolitan scale exacerbates these challenges. Due to the inconsistent definitions of city and metropolis, the (lack of) comparability of indicators across geographies is a key issue (furthermore, existing city and metropolitan-level indicators and indices rarely specify at which scale they correspond to). Indicators to measure urban areas at the global level need to be chosen carefully, ensuring the feasibility of data collection in cities of the developing world.

\subsection{Selection of indicators}

The research reported here aimed to develop a system of indicators and collect the corresponding data for a set of major cities and metropolitan areas. The goal was going beyond the city proper in order to promote a better overview of metropolitan dynamics. The first step was selecting indicators for the six priority areas set out by Metropolis (these categories reflect the association's vision of metropolitan governance), namely: (A) context and governance, (B) economic development, (C) social cohesion, (D) gender equality, (E) environmental sustainability, and (F) quality of life. To do this, we first performed an extensive review of the academic literature and of dozens of global reports, indexes and datasets produced by various organisations (e.g. C40, CIPPEC, GIZ, IDB, Lincoln Institute, OECD, Oxford Economics, UCLG, UN-Habitat, and so on). The initial ambition was to select around 30 indicators balanced across the six blocks of information.

In the selection process - and always in consultation with Metropolis - we prioritised indicators that have an established/published methodology with publicly available data. Reflecting Metropolis' concerns, we also tried to adopt a gender perspective during this process, by giving preference to indicators and sources with data disaggregated by sex, whenever possible. The other guiding concerns were data availability across all continents and comparability/rationality of collecting metropolitan data in diverse urban contexts. In the end, we singled out the 38 indicators shown in Table 1. Data for 35 of these indicators was obtained through desk research - i.e. international bodies/observatories, national statistic offices, city authorities' data, academic references or NGOs and associations - and the remaining three are newly developed and fed through a survey sent to government representatives of the 58 metropolises (namely, A4, B6 and D4 in Table 1).

Table 1. Set of metropolitan indicators (detailed sources, methodology and units available online as supplementary material).

\begin{tabular}{|c|c|c|c|c|c|}
\hline $\begin{array}{l}\text { A. Context \& } \\
\text { governance }\end{array}$ & $\begin{array}{l}\text { B. Economic } \\
\text { development }\end{array}$ & $\begin{array}{l}\text { C. Social } \\
\text { cohesion }\end{array}$ & D. Gender equality & $\begin{array}{l}\text { E. Environmental } \\
\text { sustainability }\end{array}$ & F. Quality of life \\
\hline $\begin{array}{l}\text { 1. Metropolitan } \\
\text { population** }\end{array}$ & 1. GDP per capita & 1. Literacy* & $\begin{array}{l}\text { 1. Share of elected } \\
\text { women }\end{array}$ & 1. Air quality & $\begin{array}{l}\text { 1. Life } \\
\text { expectancy* }\end{array}$ \\
\hline 2. Metropolitan area & $\begin{array}{l}\text { 2. Employment share } \\
\text { by sector }\end{array}$ & $\begin{array}{l}\text { 2. Poverty } \\
\text { rate** }\end{array}$ & $\begin{array}{l}\text { 2. Women in } \\
\text { workforce }\end{array}$ & 2. Carbon emissions & $\begin{array}{l}\text { 2. Affordability } \\
\text { of housing }\end{array}$ \\
\hline 3. Density & $\begin{array}{l}\text { 3. Economic } \\
\text { prominence }\end{array}$ & $\begin{array}{l}\text { 3. Income } \\
\text { inequality }\end{array}$ & $\begin{array}{l}\text { 3. Female school-aged } \\
\text { population enrolled }\end{array}$ & 3. Car ownership & $\begin{array}{l}\text { 3. Access to public } \\
\text { transport }\end{array}$ \\
\hline $\begin{array}{l}\text { 4. Leadership of } \\
\text { policy sectors }^{\mathrm{a}}\end{array}$ & 4. Unemployment** & $\begin{array}{l}\text { 4. Foreign born } \\
\text { population* }\end{array}$ & $\begin{array}{l}\text { 4. Measures and tools } \\
\text { on gender equality }\end{array}$ & 4. Green space & $\begin{array}{l}\text { 4. Higher education } \\
\text { enrolment* }\end{array}$ \\
\hline $\begin{array}{l}\text { 5. Fiscal } \\
\text { decentralisation }\end{array}$ & 5. Economic density & 5. Murder rate* & 5. Gender pay gap & $\begin{array}{l}\text { 5. Waste generated } \\
\text { per capita }\end{array}$ & $\begin{array}{l}\text { 5. Fragile Cities } \\
\text { Index }\end{array}$ \\
\hline $\begin{array}{l}\text { 6. Territorial } \\
\text { fragmentation }\end{array}$ & $\begin{array}{l}\text { 6. Informal } \\
\text { economy }^{\mathrm{a}}\end{array}$ & & & $\begin{array}{l}\text { 6. Wastewater } \\
\text { collection coverage }\end{array}$ & \\
\hline $\begin{array}{l}\text { 7. Metropolitan } \\
\text { coordination }\end{array}$ & & & & $\begin{array}{l}\text { 7. Renewable } \\
\text { energy use }\end{array}$ & \\
\hline \multicolumn{6}{|l|}{$\begin{array}{l}\text { 8. National } \\
\text { prominence }\end{array}$} \\
\hline \multicolumn{6}{|l|}{ 9. Fiscal autonomy } \\
\hline $\begin{array}{l}\text { 10. Total budget per } \\
\text { capita }\end{array}$ & & & & & \\
\hline
\end{tabular}


** data disaggregated by sex and age

\section{Defining metropolitan areas}

As mentioned in the introduction, there is no clear and mutually agreed definition for a 'metropolis' (European Commission, 2014; ESPON, 2018). Even in remote sensing mapping efforts, there is no generally accepted standard for what configures 'urban land' (Potere et al., 2009; Taubenböck et al., 2019). By definition, without coherent and rigorous delineation of metropolitan areas, a dataset for a specific location is, strictly speaking, not comparable to another. Four main approaches have been commonly adopted to address this problem and develop metropolitan databases. All of these approaches - summarised in Table 2 - have advantages and disadvantages in terms of feasibility, cost, and potential to capture different metropolitan dynamics. Indeed, setting the metropolitan boundaries is a complex and potentially contentious task in itself. But the extent to which one can access data that fits those boundaries is also a key issue.

Table 2. Units of analysis used for measuring urban areas.

\begin{tabular}{|c|c|c|c|}
\hline Unit of analysis & Guiding perspective & Description & Examples of studies \\
\hline $\begin{array}{l}\text { Administrative } \\
\text { boundary }\end{array}$ & Political & $\begin{array}{l}\text { Territory contained within the legally defined } \\
\text { municipal boundaries. }\end{array}$ & WCCD (2017) \\
\hline $\begin{array}{l}\text { Urban } \\
\text { agglomeration / } \\
\text { urbanised area }\end{array}$ & Demographic & $\begin{array}{l}\text { Area contained within a contiguous territory } \\
\text { inhabited at certain population density levels } \\
\text { (threshold varies by country) without regard } \\
\text { to administrative boundaries. }\end{array}$ & Rozenfeld et al. (2008) \\
\hline Urban footprint & Physical & $\begin{array}{l}\text { Extent of contiguous built-up area, measured } \\
\text { using high-resolution satellite data. }\end{array}$ & Sharma et al. (2016) \\
\hline $\begin{array}{l}\text { Metropolitan } \\
\text { area/functional } \\
\text { urban area }\end{array}$ & Functional & $\begin{array}{l}\text { Large urban core plus adjacent areas with a } \\
\text { high degree of economic and social } \\
\text { integration, most commonly measured using } \\
\text { population density, employment, and } \\
\text { commuting data (thresholds vary by country) } \\
\text { - areas tend to include communities that are } \\
\text { physically separated from the main urban } \\
\text { core. }\end{array}$ & $\begin{array}{l}\text { OECD (2019); US OMB } \\
\text { (2010) }\end{array}$ \\
\hline Hybrid & $\begin{array}{l}\text { Demographic, physical } \\
\text { and functional }\end{array}$ & A mix of the approaches above. & $\begin{array}{l}\text { Angel et al. (2016); } \\
\text { Burdett and Rode (2018); } \\
\text { UN (2018) }\end{array}$ \\
\hline
\end{tabular}

By comparing the population living within the administrative boundaries controlled by a sub-national government (typically a local government led by a mayor), and the extent of the "wider functional metropolitan' area of 35 cities, Burdett et al. (2014) concluded that only three cases showed a 'perfect' fit between the two (see Figure 1). Due to this general discrepancy and the difficult task of standardising data collection and treatment, many metrics and measurement efforts misconstrue the dynamics of urban areas by only providing a snapshot of the socio-economic conditions of the city proper.

To tackle this problem, the OECD undertook a major study to identify and analyse 1,148 functional urban areas beyond their administrative boundaries and set up the OECD Metropolitan database for 649 metro areas in 33 OECD countries (OECD, 2012 and 2019). However, OECD's sophisticated three-step method to define metropolitan areas requires detailed commuting and labour market data. In practice, it is extremely difficult (and/or costly) to apply this approach to identify metro areas in jurisdictions where there is data scarcity - and it is even more difficult to collect other data at the scale of these custom-made geographies. Producing a generic database that encompasses metropolitan areas from all over the world, may require simpler, less ambitious approaches to the definition of the metropolitan boundaries. 

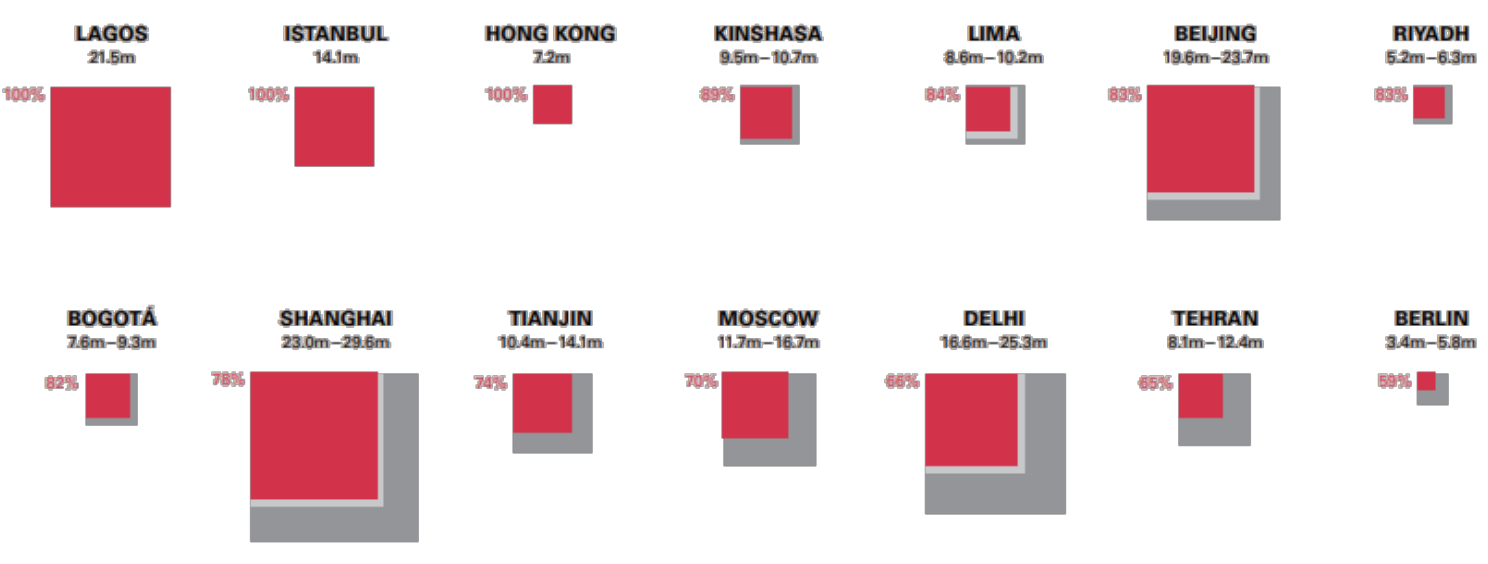

BERLIN

E9:5
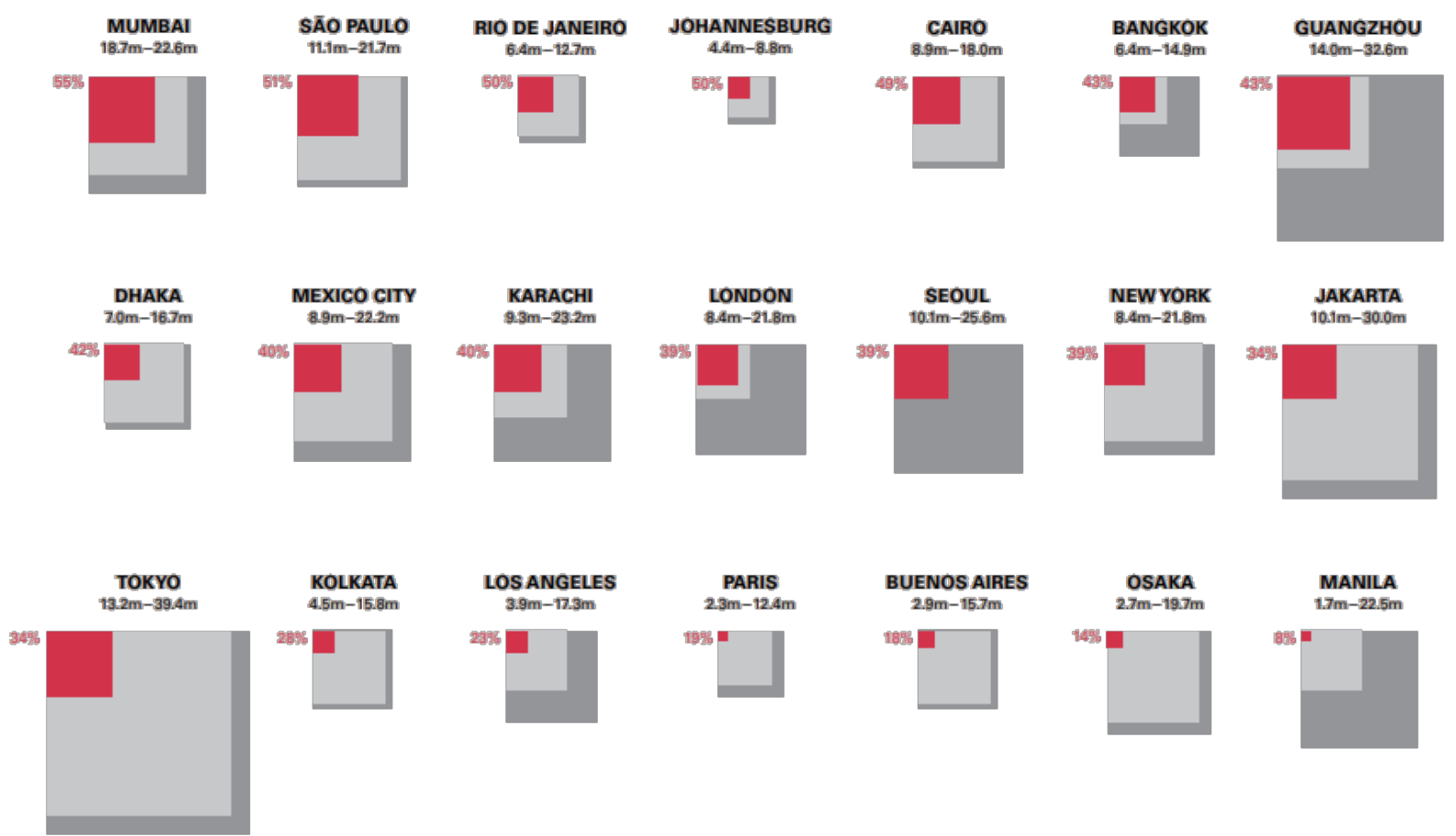

Figure 1. Fit between the political city and functional area. City population in red, lowest estimate of metropolitan population in light grey and highest estimate of metropolitan population in dark grey (source: Burdett et al., 2014).

In this study, we aimed to develop a simple heuristic process, applicable to metropolises from all continents, that allowed us to capture these dynamics in a quick and inexpensive way and to push beyond the limitations of existing global databases. In a nutshell, the intention was to find a 'good enough' fit between administrative (and/or statistical) and metropolitan areas. By doing this, we hope to facilitate access to government-produced information and official statistics at a suitable geographic level. The first thing we did in this regard was to estimate the 'metropolitan populations' of the 58 members of Metropolis (see the Appendix) by averaging the data from various sources that use different methodologies. The global metropolitan databases we have used include the Atlas of Urban Expansion, Oxford Economics, United Nations Population Division, OECD Metropolitan eXplorer, Demographia, Citymayors.com and Africapolis. We used at least five sources for each metropolis ${ }^{3}$, which allowed us to obtain a better estimation of the 'real' metropolitan population.

We then adopted a four-step procedure to identify the most relevant boundaries of the 58 metropolises - the detailed process is illustrated in Figure 2. In Steps 1 to 3, we test different administrative and statistical areas by comparing their populations with the average metropolitan populations. If these areas can 'sufficiently' represent the metropolises, this should expedite the data collection for the 38

\footnotetext{
${ }^{3}$ Except for Antananarivo and Jakarta with only four sources.
} 
indicators mentioned in the previous section whilst also minimising biases to the realities of the 58 metropolitan areas. If the population of an administrative/statistical area is within the range of $75 \%$ to $125 \%$ of the estimated metropolitan population, we consider it as the proxy of the metropolitan area. ${ }^{4}$ In Step 4, we bundle adjacent administrative areas to delineate a suitable metropolitan area. To decide which neighbouring areas should be included, we reviewed relevant literature and considered the urban population of each area from the census data (the $75 \%$ to $125 \%$ limits were also adopted in this Step).

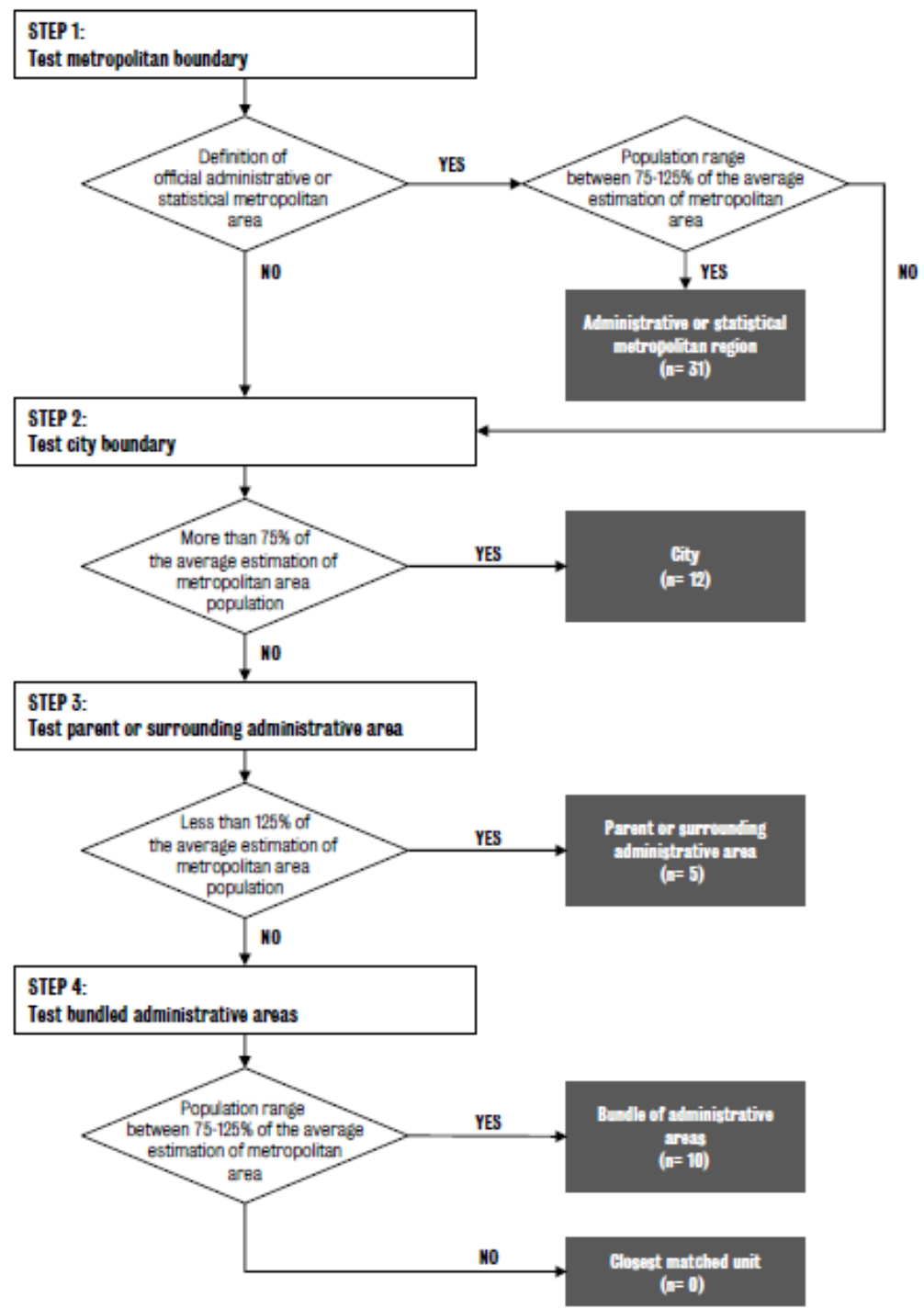

Figure 2. Heuristic process for defining metropolitan areas.

Following this methodology, we defined 31 metropolitan areas in Step 1, 12 in Step 2, five in Step 3, and 10 in Step 4 (see the Appendix for detail about each metropolis). Indeed, the boundaries set through this approach often coincide with the administrative or statistical boundaries that were set out nationally for the metropolitan area. However, there are a few cases for which this is not adequate (e.g. if a large percentage of the metropolitan population lives outside those administrative or statistical boundaries). There are also many instances where no nationally-defined administrative/statistical metropolitan area exists. In some cases, the 'project boundaries' correspond to the boundaries of the authority that holds membership in the Metropolis network. In other cases, the administrative/political boundaries of the members of Metropolis differ from the ones of the

\footnotetext{
${ }^{4}$ The $\pm 25 \%$ range was arbitrarily chosen by the research team. Smaller ranges (e.g. $\pm 10 \%$ or $\pm 5 \%$ ) would be more restrictive and lead to more metropolitan areas defined through Step 4.
} 
targeted metropolitan areas. The procedure always returns a solution to the boundaries of the metropolises. Even in cases for which it is impossible to find administrative/statistical areas or bundles of areas that contain $75 \%$ to $125 \%$ of the estimate of the 'metropolitan population', Step 4 makes sure we obtain a proxy for the metropolitan area (by returning the closest bundle of areas, e.g. $74 \%$ or $127 \%$ of the population).

The heuristic developed here does not configure a sophisticated approach to define the boundaries of metropolitan of 'functional' areas. But it is particularly useful to collect 'some' data at the metropolitan scale and to provide an overview of various socioeconomic aspects of these human settlements around the globe. Other methods using urban footprints and various thresholds may provide more precise or meaningful boundaries for metropolitan areas - but such methods are also resource-intensive and are not capable of circumventing problems of data scarcity, which are very significant in various jurisdictions. After deciding which 'urban cells' should be included in the metropolitan area one needs to collect the data for those cells and, whichever the method (census, surveys, local monitors and sensors, remote sensing, etc.), data collection entails a significant financial investment. There is a clear trade-off that needs to be negotiated in metropolitan empirical research: the accuracy of the data versus the comprehensiveness of dataset.

\section{Data collection}

The set of 58 metropolises included in this study was jointly decided with Metropolis (see the Appendix for a full list). There was an attempt to target more members from the Global South - for which less data is usually available - but the overall feasibility of the process was also a key factor which we have considered. We collected data for 17 metropolises from Africa, 14 from Asia, 11 from Europe, 13 from Latin America and the Caribbean, and three from Northern America (Metropolis does not have members in Oceania).

After developing a method for setting the boundaries of metropolitan areas, we needed to adopt a procedure to prioritise urban datasets and collect the most relevant data at the metropolitan scale. As discussed above, we had to strike a balance between the comparability and the comprehensiveness of the data (and also the overall feasibility of the process, given the resource constraints). We always searched for the closest possible boundary or level of information for each indicator, namely: if the information was not available at the metropolitan level, we looked for that data point at the city level; if it was also not available at the city level, we looked for it at the regional level; if it was also not available at the regional level, we looked for it at the national level. A missing data point means that the information was not available at any of those scales. In terms of data sources, with the exception of the three indicators fed through the survey, the following prioritisation was adopted (in an attempt to minimise the problems of different standards/methodologies in different countries or jurisdictions):

1. International bodies/observatories;

2. National statistics offices;

3. City authorities' data;

4. Academic references;

5. NGOs and associations.

This strategy allowed us to build a very comprehensive dataset with less than $10 \%$ missing data points (if we exclude the survey data). However, due to data (un)availability, some indicators have different boundaries (or levels of information) within a particular metropolis and, in a few cases, different metropolises will have different boundaries for the same indicators. Still, $61 \%$ of the data was collected at the metropolitan level, and only $14 \%$ corresponds to the city level, $3 \%$ to the regional level, and $22 \%$ to the national level. This means that the data collected is also highly 'comparable' across metropolises, especially if we take into account that $75 \%$ of the data is 'urban' (city and metrolevel). Given the breadth of metropolises included in the database, the information is also surprisingly 
up-to-date: around $80 \%$ of the data relates to the last five years (and around $95 \%$ was collected after 2010).

The data was collected one indicator at a time (instead of all indicators for each metropolis). With this approach, we avoided coding biases and saved time when the data was retrieved from the same international databases for different metropolises. After all data was collected, representatives from each of the 58 metropolises received a three-page 'data profile' so that the members of Metropolis could validate the accuracy of the data, sources and methods. ${ }^{5}$ In a few cases, the representatives sent suggestions for more up-to-date or accurate figures for certain indicators (which we accepted, in most instances).

\section{Overview of data and potential for analysis}

All the data collected for this study is available online at the 'Metropolitan Observatory' platform (https://indicators.metropolis.org). In this section, we present the results for a handful of the indicators and explore the value of the assembled dataset for metropolitan governance and sustainable development stakeholders. Naturally, given the limitations mentioned above (the presence of different scales, years and methodologies), the use of sophisticated statistical methods is not advisable. But testing the relationships (or lack thereof) between two or more indicators to understand the interactions between various phenomena may be useful for actors concerned with particular policy sectors. In addition, as illustrated in Figure 3, the dataset allows for the rendering of global snapshots of metropolitan dynamics.

Mapping the results helps to hypothesise about the (non-)existence of patterns across metropolitan areas from different parts of the world. For example, as Figure 3 shows, European and Northern American metropolitan areas may be wealthier, but they also have considerably smaller population sizes when compared to their counterparts in Latin America and Asia. African metropolises are among the poorest and are still relatively small - but the continent's population will more than double in 30 years, representing more than half of the anticipated growth in global population (UN, 2017b). Despite being poorer in per capita terms, our data also shows that metro areas in Africa, Asia and Latin America produce a significant share of the national economic output (indicator B3). Taken together, it becomes quite clear that boosting the economic development of metropolitan areas in the South should be a global priority as it would have a substantial impact on the wellbeing on a very large share of the planet's population.

With regards to indicators that could explain the outcomes measured through other indicators, our data could at least serve as a 'conversation starter' for more in-depth analyses. For example, income inequality seems to be a much better predictor of murder rate (correlation coefficient: $0.3351, \mathrm{p}$-value: 0.0101 ) than poverty (correlation coefficient: 0.1556 , p-value: 0.2435 ) or unemployment (correlation coefficient: 0.152 , p-value: 0.2548 ) in the 58 metropolitan areas (see Figure 4). This type of finding may be critical for policy-makers set out to design responses for particular challenges.

\footnotetext{
${ }^{5}$ Alongside the 'data profiles' each member of Metropolis also received (1) the raw data for their metropolis (where they were able to check the sources of the data and the units, scale and year of each data point), (2) the methodology we adopted to set the boundaries, and (3) the description of the indicators (see the online supplementary material).
} 


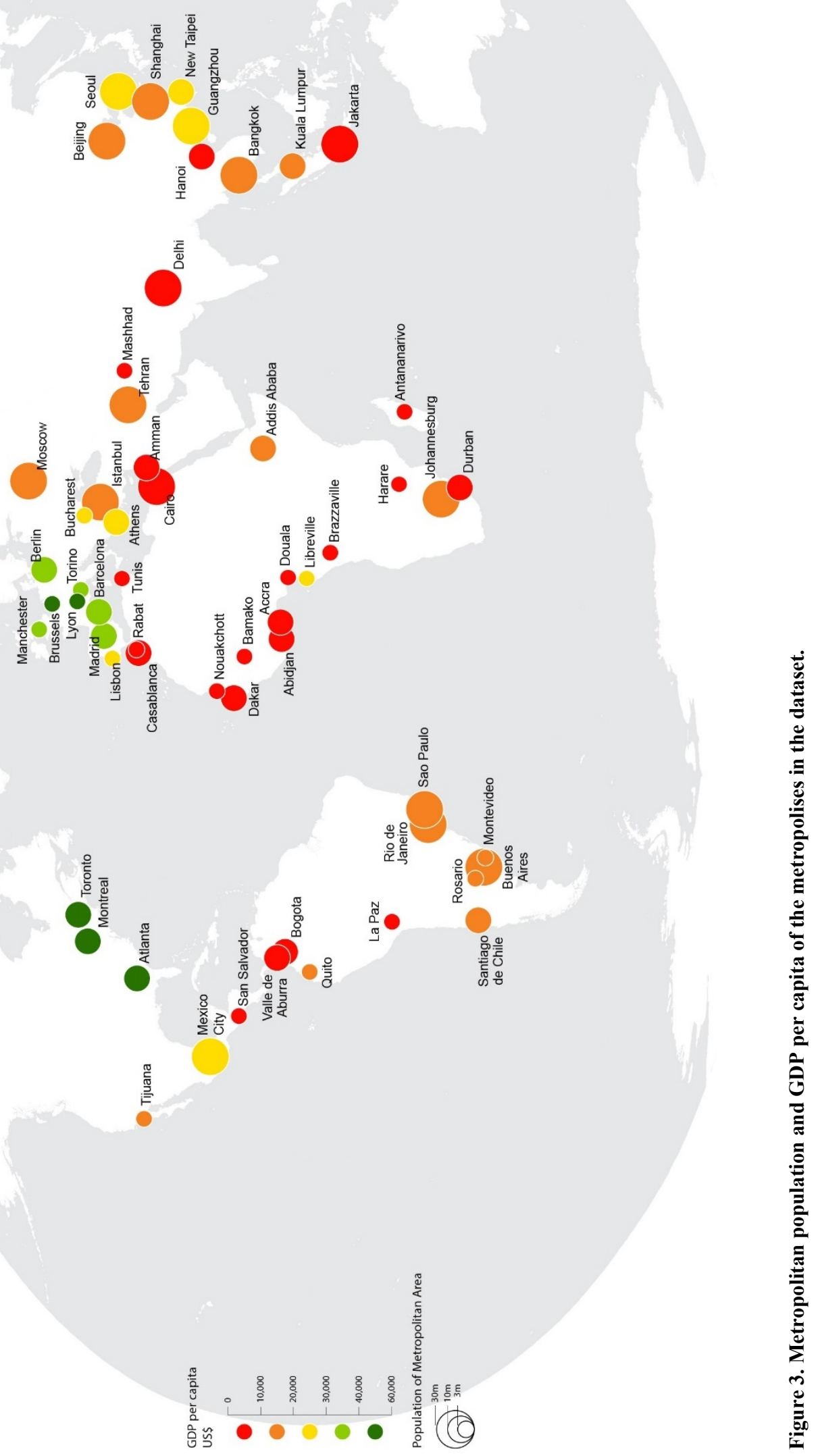



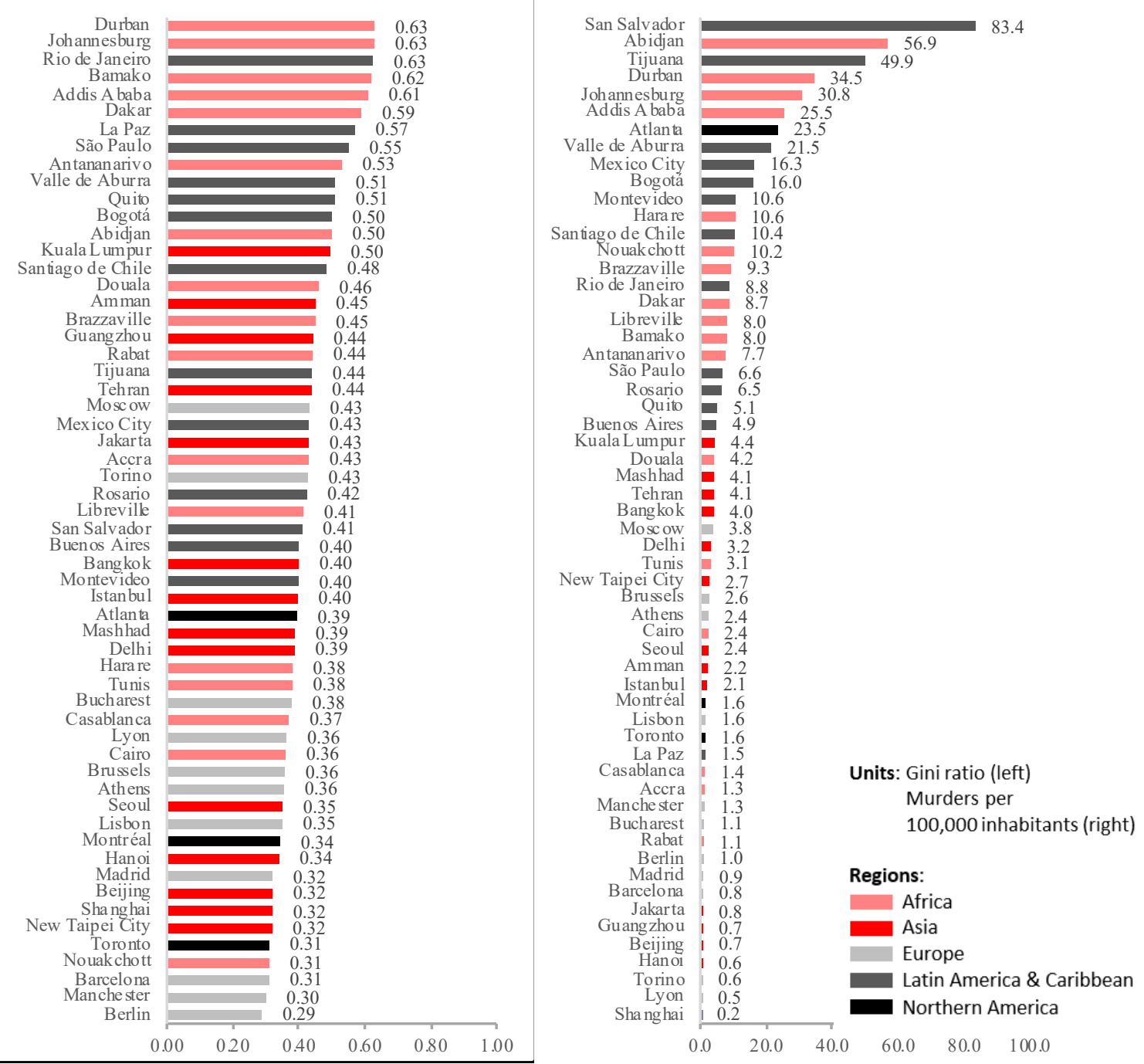

Figure 4. Income inequality (left) and murder rate (right) comparison.

Some of the results may also challenge preconceptions, for example, regarding the divide between high-income and low-income countries. Considering the share of elected women in local government (D1), if we look into the top quintile (12 metros) of the 58 metropolitan areas, we obtain five metro areas from Latin America and the Caribbean and two from Africa (with none from Asia). This suggests that, in certain aspects, metropolitan areas in low-income countries may have better practices than ones in high-income countries. Still, according to the data collected through a survey for indicator A4, gender equality seems to be the area in which metropolitan-level governments are less able to influence policy (see Figure 5). Tackling gender inequality requires cooperation across tiers of government.

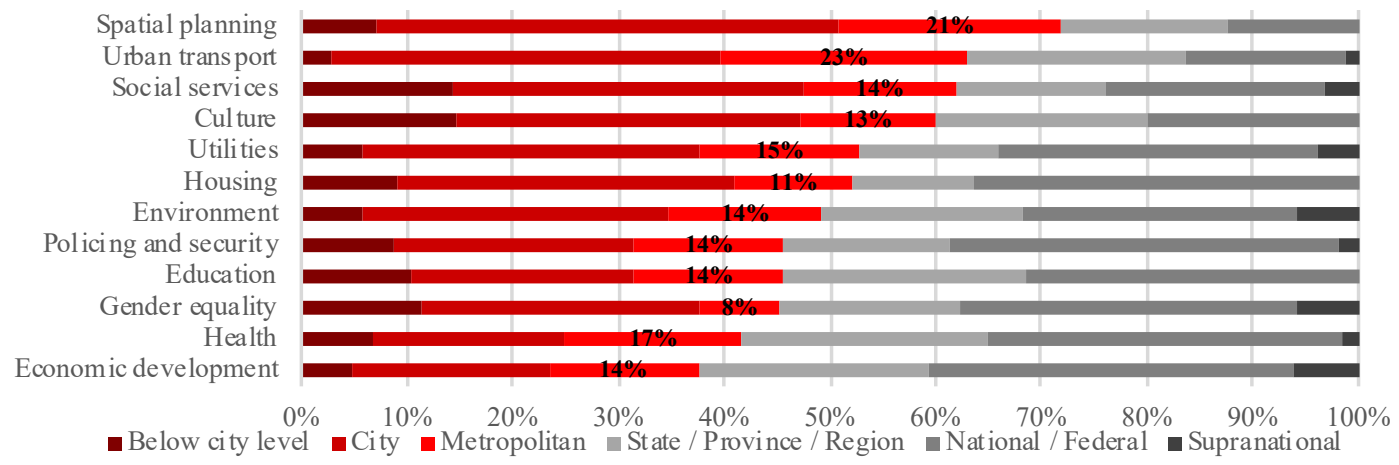

Figure 5. "Please rate the level of influence that different tiers of government have over decision-making in your metropolis for the following policy sectors." 
The results shown in Figure 5 and the ones obtained for indicator A7 (see Figure 6) call for more research into and a better understanding of metropolitan governance frameworks around the world. The level of coordination varies widely among the metropolitan areas irrespective of their region and size. Likewise, the ability of metropolitan-level governments to influence policy differs from sector to sector. Metropolises have considerable influence on spatial planning and urban transport issues but, in addition to gender equality, have relatively less power on issues such as housing, economic development and education. To enhance our understanding of the way governance works in cities and metropolitan areas, we will first need to generate new methodologies and empirical insights that capture its multi-scalar nature (da Cruz et al., 2019).

5: There is a metropolitan government/supra municipal structure $(n=25)$

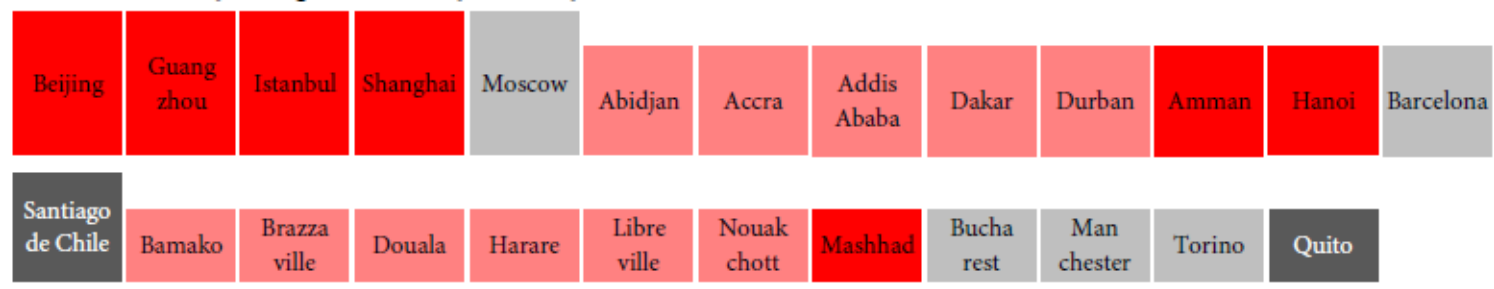

4: There is a multipurpose/strategic mechanism for formal cooperation and all jurisdictions within the metro area participate on it $(n=9)$

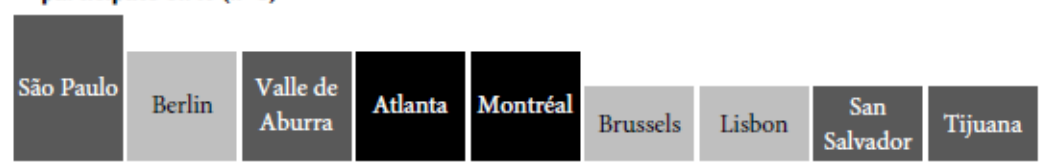

3: There is a multi-purpose/strategic mechanism for formal cooperation but not all jurisdictions participate on it $(n=6)$

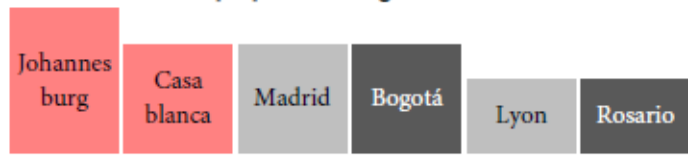

2 = There is a sectoral/single purpose mechanism for formal cooperation and all jurisdictions participate $(n=9)$

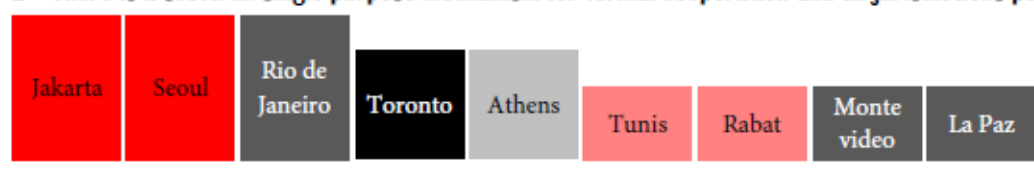

$1=$ There is a sectoral/single purpose mechanism for formal cooperation but not all jurisdictions participate at all $(\mathrm{n}=6)$
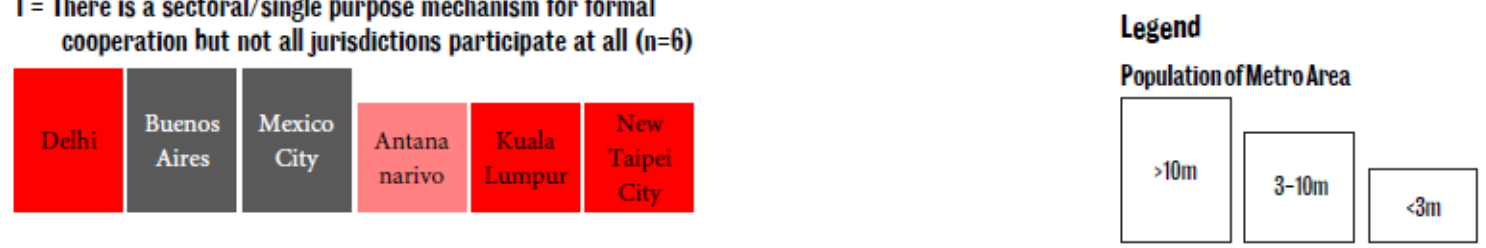

$0=$ No formal coordination mechanism $(\mathrm{n}=3)$
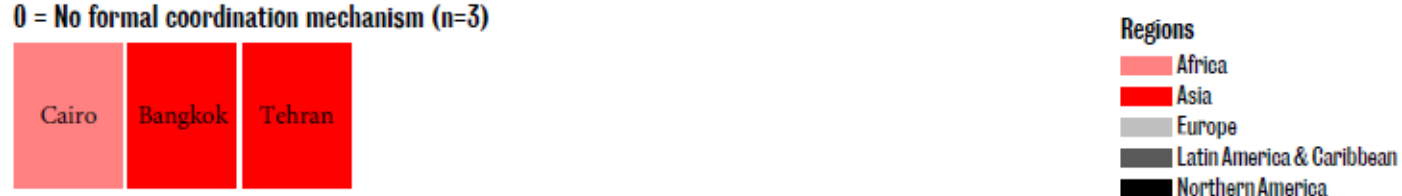

Figure 6. Metropolitan coordination.

\section{Conclusion}

Presumably due to the ambiguity of the concept of 'metropolitan area', international databases with information at this territorial scale are very limited. At the same time, there is a global recognition that metropolitan management and governance matters, and that better data and measurement 
harmonisation are urgently needed - a concern that was broadly emphasised, for example, during the Habitat III process and in the final text of the New Urban Agenda (UN, 2017a). Behind this concern lies the belief that the creation of a strong system of cities and metropolitan areas can contribute to a balanced regional socio-economic development. To achieve this, the various stakeholders will require access to a vast array of relevant and comparable data - otherwise, the current expectations being placed onto cities and metropolitan areas may clash with the realities in terms of their aptitudes and capacities.

This essay illustrates the complexities behind gathering data for metropolises from across the globe. We highlight these challenges by collecting data on 38 indicators for 58 metropolitan areas. An integral part of this process was the development of effective heuristics to cope with the challenges, namely: setting the boundaries of the metropolitan areas and collecting data from diverse sources and jurisdictions. It is very important to note that these issues - boundaries and indicators that capture metropolitan dynamics and inequalities - are not merely technical. For example, in Addis Ababa, the planned expansion of the metropolitan boundaries into surrounding territories - which was foreseen in the previous version of the Ethiopian capital's 'masterplan' - resulted in violent clashes that claimed many lives (Chala, 2016). In a starkly different way, there has been some support in Malmö and the Swedish province of Skåne to rebrand that territory as 'Greater Copenhagen', the capital of Denmark (Crouch, 2015). Different yet, Transport for London, the metropolitan transport authority of London, pushed for taking over national rail services that expand into the wider region. Metropolitan boundaries and their socio-economic dynamics are intrinsically political.

The resulting dataset has several limitations. It may not be appropriate for robust quantitative academic inquiries. However, it provides an invaluable starting point for a far-reaching empirical research agenda on metropolitan areas and governance. It can also offer preliminary insights into how different socio-economic aspects of metropolitan areas are interlinked. This paper contributes to the literature in two main ways: 1) by providing a simple heuristic to define 'good enough' metropolitan areas and collect data at that level, and 2) by highlighting the limitations of current empirical research and knowledge about metropolitan dynamics and, consequently, the uncertainty that surrounds their ability to face the intractable challenges of our times. Finally, it is important to stress that, whilst necessary, collecting data at the 'right' scale is not sufficient to re-scale urban governance (Brenner, 1999). Furthermore, this re-scaling is contentious and can be of different types (OECD, 2015) - there are no 'one-size-fits-all' solutions for governance reforms.

\section{References}

Ahrend, R., Gamper, C., \& Schumann, A. (2014). The OECD Metropolitan Governance Survey: A Quantitative Description of Governance Structures in large Urban Agglomerations. Regional Development Working Papers. OECD: Paris.

Angel, S. (2017). Urban forms and future cities: a commentary. Urban Planning, 2(1), 1-5.

Angel, S., Blei, A.M., Parent, J., Lamson-Hall, P., \& Sánchez, N.G. (2016). Atlas of Urban Expansion - 2016 Edition, Volume 1: Areas and Densities. New York University, UN-Habitat, and the Lincoln Institute of Land Policy: New York.

Angel, S., Parent, J., \& Civco, D. (2012). The fragmentation of urban landscapes: global evidence of a key attribute of the spatial structure of cities, 1990-2000. Environment \& Urbanization, 24(1), 249-283.

Baum-Snow, N. (2007). Did highways cause suburbanization? Quarterly Journal of Economics, 122(2), 775-805.

Brenner, N. (1999). Globalisation as reterritorialisation: the re-scaling of urban governance in the European Union. Urban Studies, 36(3), 431-451.

Burdett, R., \& Rode, P. (2018). Shaping Cities in an Urban Age. Phaidon: London.

Burdett, R., Rode, P., Shankar, P., \& Vahidy, S. (2014). Governing urban futures. London School of Economics \& Political Science: London. 
Chala, R. (2016). "Ethiopia scraps Addis Ababa 'master plan' after protests kill 140.” The Guardian, https://www.theguardian.com/world/2016/jan/14/ethiopia-addis-master-plan-abandoned Accessed 14 June 2019.

Crouch, D. (2015). "Denmark wants to rebrand part of Sweden as 'Greater Copenhagen'." The Guardian, https://www.theguardian.com/world/2015/mar/05/denmark-wants-to-rebrand-part-ofsweden-as-greater-copenhagen Accessed 14 June 2019.

da Cruz, N.F., Berg, S.V., \& Marques, R. (2013). Managing public utilities: lessons from Florida. Lex Localis, 11(2), 101-118.

da Cruz, N.F., Rode, P., McQuarrie, M. (2019). New urban governance: a review of current themes and future priorities. Journal of Urban Affairs, 41(1), 1-19.

d'Albergo, E., \& Lefèvre, C. (2018). Constructing metropolitan scales: economic, political and discursive determinants. Territory, Politics, Governance, 6(2), 147-158.

d'Albergo, E., \& Lefèvre, C., \& Ye, L. (2018). For a political economy of metropolitan scale: the role of public-private relations. Territory, Politics, Governance, 6(2), 182-198.

ESPON (2018). Spatial Dynamics and Strategic Planning in Metropolitan Areas. European Observation Network for Territorial Development and Cohesion: Luxembourg.

European Commission (2014). A harmonised definition of cities and rural areas: the new degree of urbanisation. Working Paper No. 01/2014, European Commission: Brussels.

Gómez-Álvarez, D., Rajack, R., López-Moreno, E., \& Lanfranchi, G. (2017). Steering the Metropolis. Inter-American Development Bank: Washington.

Guzman, L.A., Oviedo, D., \& Bocarejo, J.P. (2017). City profile: The Bogotá Metropolitan Area that never was. Cities, 60, 202-215.

Hoornweg, D., Ruiz Nuñez, F., Freire, M., Palugyai, N., Villaveces, M., \& Herrera, E.W. (2007). City Indicators: Now to Nanjing. Policy Research Working Paper No. 4114. World Bank: Washington, DC.

Klopp, J., \& Petretta, D. (2017). The urban sustainable development goal: indicators, complexity and the politics of measuring cities. Cities, 63, 92-97.

OECD (2012). Redefining 'Urban': A New Way to Measure Metropolitan Areas. OECD Publishing: Paris.

OECD (2015). Governing the City. OECD Publishing: Paris.

OECD (2019). The OECD Metropolitan eXplorer - User Guide. OECD: Paris.

Potere, D., Schneider, A., Angel, S., \& Civco, D.L. (2009) Mapping urban areas on a global scale: which of the eight maps now available is more accurate? International Journal of Remote Sensing, 30(24), 6531-6558.

Phelps, N.A. (2010). Suburbs for nations? Some interdisciplinary connections on the suburban economy. Cities, 27, 68-76.

Rode, P., Heeckt, C., \& da Cruz, N.F. (2019). National transport policy and cities: key policy interventions to drive compact and connected urban growth. Coalition for Urban Transitions: London and Washington, DC.

Rozenfeld, H.D., Rybski, D., Andrade, J.S., Batty, M., Stanley, H.E., \& Makse, H.A. (2008). Laws of population growth. PNAS, 105(48), 18702-18707.

Sayer, J., Campbell, B., Petheram, L., Aldrich, M., Perez, M.R., Endamana, D., Dongmo, Z.N., Defo, L., Mariki, S., Doggart, N., \& Burgess, N. (2007). Assessing environment and development outcomes in conservation landscapes. Biodiversity and Conservation, 16(9), 2677-2694.

Sharma, R.C., Tateishi, R., Hara, K., Gharechelou, S., \& Iizuka, K. (2016). Global mapping of urban built-up areas of year 2014 by combining MODIS multispectral data with VIIRS nighttime light data. International Journal of Digital Earth, 9(10), 1004-1020.

Stern, N., \& Zenghelis, D. (2018). 'Locking cities', in Burdett, R., Rode, P. (Eds.) Shaping Cities in an Urban Age, London: Phaidon, pp. 270-277.

Taubenböck, H., Weigand, M., Esch, T., Staab, J., Wurm, M., Mast, J., \& Dech, S. (2019). A new ranking of the world's largest cities-Do administrative units obscure morphological realities? Remote Sensing of Environment, 232, 111353.

Tomlinson, R. (2017). An argument for metropolitan government in Australia. Cities, 63, 149-153. UN (2017a). New Urban Agenda. United Nations General Assembly: New York. 
UN (2017b). World Population Prospects: The 2017 Revision, Key Findings and Advance Tables. Working Paper No. ESA/P/WP/248, United Nations: New York.

UN (2018). World Urbanization Prospects: The 2018 Revision, Methodology. Working Paper No. ESA/P/WP.252, United Nations: New York.

US OMB (2010). Standards for Delineating Metropolitan and Micropolitan Statistical Areas. United States Office of Management and Budget. Federal Register, 75(123), 37246-37252.

WCCD (2017). WCCD city data for the United Nations Sustainable Development Goals. https://www.dataforcities.org/publications Accessed 14 June 2019.

Westfall, M., \& de Villa, V.A. (2001). Urban Indicators for Managing Cities. Asian Development Bank: Manila. 


\section{Appendix}

Set of metropolises included in the database

\begin{tabular}{|c|c|c|c|}
\hline Metropolis & UN Region & Country & Metropolitan area adopted \\
\hline Douala & Africa & Cameroon & Communauté Urbaine de Douala (Step 2) \\
\hline Brazzaville & Africa & Congo & Commune de Brazzaville (Step 2) \\
\hline Cairo & Africa & Egypt & Cairo, Giza, and Qalyubia Governorates (Step 4) \\
\hline Addis Ababa & Africa & Ethiopia & Addis Ababa City Government (Step 2) \\
\hline Libreville & Africa & Gabon & Commune de Libreville (Step 2) \\
\hline Accra & Africa & Ghana & Greater Accra Region (Step 3) \\
\hline Abidjan & Africa & Ivory Coast & $\begin{array}{l}\text { District Autonome d'Abidjan (Step 1) } \\
\text { Antananarivo-Renivohitra, Antananarivo-Avaradrano and }\end{array}$ \\
\hline Antananarivo & Africa & Madagascar & Antananarivo-Atsimondrano Districts (Step 4) \\
\hline Bamako & Africa & Mali & Gouvernorat du District de Bamako (Step 2) \\
\hline Casablanca & Africa & Morocco & $\begin{array}{l}\text { Préfecture de Casablanca, Province de Mediouna, Province de } \\
\text { Nuaceur and Préfecture de Mohammedia (Step 4) } \\
\text { Prefecture de Rabat, Prefecture de Sale and Prefecture de }\end{array}$ \\
\hline Rabat & Africa & Morocco & Skhirat-Temara (Step 4) \\
\hline Nouakchott & Africa & Mauritania & Nouakchott City (Step 2) \\
\hline Dakar & Africa & Senegal & Région de Dakar (Step 1) \\
\hline Durban & Africa & South Africa & $\begin{array}{l}\text { Ethekwini Municipality (Step 1) } \\
\text { City of Johannesburg, City of Ekurhuleni, and City of }\end{array}$ \\
\hline Johannesburg & Africa & South Africa & Tshwane (Step 4) \\
\hline Tunis & & Tunisia & Tunis, Ben Arous, Ariana and Manouba Governorates (Step \\
\hline & Africa & & 4) \\
\hline Harare & Africa & Zimbabwe & Harare Province (Step 3) \\
\hline Beijing & Asia & China & Beijing Municipality (Step 2) \\
\hline Guangzhou & Asia & China & Guangzhou Municipality (Step 2) \\
\hline Shanghai & Asia & China & Shanghai Province (Step 1) \\
\hline Delhi & Asia & India & $\begin{array}{l}\text { Delhi NCT, Jhajjar, Sonipat, Gurgaon, Faridabad, Baghpat, } \\
\text { Ghaziabad, Gautam Buddha Nagar (Step 4) }\end{array}$ \\
\hline Jakarta & Asia & Indonesia & Jabodetabek (Step 1) \\
\hline Mashhad & Asia & Iran & Mashhad Municipality (Step 2) \\
\hline Tehran & Asia & Iran & $\begin{array}{l}\text { Tehran, Karaj, Shahriar, Baharestan, Qods, Fardis, } \\
\text { Eslamshahr, and Pardis counties (Step 4) }\end{array}$ \\
\hline Amman & Asia & Jordan & Greater Amman Municipality (Step 1) \\
\hline Kuala Lumpur & Asia & Malaysia & W. P. Kuala Lumpur, W. P. Putrajaya and Selangor (Step 3) \\
\hline Seoul & Asia & South Korea & Capital Region of Korea (Step 1) \\
\hline New Taipei City & Asia & Taiwan & Taipei, New Taipei and Keelung (Step 4) \\
\hline Bangkok & Asia & Thailand & $\begin{array}{l}\text { Bangkok, Nakhon Pathom, Nonthaburi, Pathum Thani, Samut } \\
\text { Prakarn, Samut Sakhon (Step 4) }\end{array}$ \\
\hline Istanbul & Asia & Turkey & Province of Istanbul (Step 1) \\
\hline Hanoi & Asia & Vietnam & Government of Hà Noi (Step 2) \\
\hline Brussels & Europe & Belgium & $\begin{array}{l}\text { Region de Bruxelles-Capitale and Provincie Vlaams-Brabant } \\
\text { (Step 3) }\end{array}$ \\
\hline Lyon & Europe & France & $\begin{array}{l}\text { Rhône, including Métropole de Lyon and Département du } \\
\text { Rhône (Step 3) }\end{array}$ \\
\hline Berlin & Europe & Germany & Landes Berlin (Step 1) \\
\hline Athens & Europe & Greece & Region of Attica (Step 1) \\
\hline Torino & Europe & Italy & Citta metropolitana di Torino (Step 1) \\
\hline Lisbon & Europe & Portugal & Área Metropolitana de Lisboa (Step 1) \\
\hline Bucharest & Europe & Romania & General Council of Bucharest (Step 2) \\
\hline Moscow & Europe & Russia & Government of Moscow (Step 2) \\
\hline Barcelona & Europe & Spain & Àmbit Metropolità de Barcelona (Step 1) \\
\hline Madrid & Europe & Spain & Comunidad de Madrid (Step 1) \\
\hline Manchester & Europe & United Kingdom & Greater Manchester (Step 1) \\
\hline Buenos Aires & Latin American \& the Caribbean & Argentina & Gran Buenos Aires (Step 1) \\
\hline Rosario & Latin American \& the Caribbean & Argentina & Área Metropolitana Rosario (Step 1) \\
\hline $\mathrm{La} \mathrm{Paz}$ & Latin American \& the Caribbean & Bolivia & Región Metropolitana de La Paz (Step 1) \\
\hline Rio de Janeiro & Latin American \& the Caribbean & Brazil & Região Metropolitana do Rio de Janeiro (Step 1) \\
\hline São Paulo & Latin American \& the Caribbean & Brazil & Região Metropolitana de São Paulo (Step 1) \\
\hline Santiago de Chile & Latin American \& the Caribbean & Chile & Región Metropolitana de Santiago de Chile (Step 1) \\
\hline Bogotá & Latin American \& the Caribbean & Colombia & Bogotá Capital District (Step 1) \\
\hline Medellin & Latin American \& the Caribbean & Colombia & Área Metropolitana del Valle de Aburrá (Step 1) \\
\hline Quito & Latin American \& the Caribbean & Ecuador & Distrito Metropolitano de Quito (Step 1) \\
\hline San Salvador & Latin American \& the Caribbean & El Salvador & Área Metropolitana de San Salvador (Step 1) \\
\hline Mexico City & Latin American \& the Caribbean & Mexico & Metropolitan Zone of the Valle de México (Step 1) \\
\hline Tijuana & Latin American \& the Caribbean & Mexico & Zona Metropolitana de Tijuana (Step 1) \\
\hline Montevideo & Latin American \& the Caribbean & Uruguay & Área Metropolitana de Montevideo (Step 1) \\
\hline Montréal & Northern America & Canada & Montreal Census Metropolitan Area (Step 1) \\
\hline Toronto & Northern America & Canada & Toronto Census Metropolitan Area (Step 1) \\
\hline Atlanta & Northern America & United States & $\begin{array}{l}\text { Atlanta-Sandy Springs-Roswell, GA Metropolitan Statistical } \\
\text { Area (Step 1) }\end{array}$ \\
\hline
\end{tabular}

